\title{
ANALISIS NILAI MORAL NOVEL ANAK SEJUTA BINTANG KARYA AKMAL NASERY BASRAL
}

\author{
Maguna Eliastuti \\ Program Studi Pendidikan Bahasa dan Sastra Indonesia \\ Fakultas Bahasa dan Seni \\ Universitas Indraprasta PGRI \\ 2@'7=Maguna.eliastuti@gmail.com Aspek bijaksana dapat dilihat pada kutiipan berikut ini.
}

\begin{abstract}
ABSTRAK
Tujuan Dari penelitian ini adalah untuk mengetahui dan mendeskripsikan tentang data empiris tentang kandungan analisis nilai moral novel Anak Sejuta Bintang. Metode yang digunakan dalam penelitian ini adalah me tode kualitatif dengan pendekatan moral, yang memfokuskan kajian analisis structural dalam studi sastra yang memberikan perhatian pada kandungan analisis moral yang terdapat pada novel Anak Sejuta Bintang karya Akmal Nasery Basral. Hasil penelitian ini menunjukkan bahwa komposisi kandungan aspek moralitas baik. Kecenderungan moral baik yang dapat peneliti temui dalam novel Anak Sejuta Bintang karya Akmal Nasery Basral dari keseluruhan temuan nilai
\end{abstract}

Kata Kunci : novel, Anak Sejuta Bintang

\begin{abstract}
The purpose of this study was to determine and describe the content of the analysis of empirical data about the moral value of the novel Anak Sejuta Bintang. The method used in this research is qualitative method with a moral approach, focusing the study of structural analysis in the study of literature that focuses on the content of moral analysis contained in the novel "Children of a Million Stars" by Akmal Nasery Basral. These results indicate that the presence of other aspects of good morality. Good moral tendency to researchers encountered in the novel Anak Sejuta Bintang by Akmal Nasery Basral of the overall findings of value
\end{abstract}

Keywords : novel, Aanak Sejuta Bintang

\section{PENDAHULUAN}

Novel Anak Sejuta Bintang merupakan sebuah novel biografis, novel ini terinspirasi dari kehidupan masa kecil dan remaja Aburizal Bakrie, terutama menjelang masuk taman kanakkanak dan semasa belajar di Sekolah Rakyat sampai menjelang Sekolah Menengah Pertama di Sekolah yang dikelola Yayasan Perwuri. Setelah membaca novel tersebut peneliti mendapati bahwa novel Anak Sejuta Bintang cukup menginspirasi dan banyak mengajarkan nilai-nilai moral, sebuah novel yang patut dibaca oleh guru, orang tua, pendidik bahkan anak-anak yang sedang berkembang dalam menemukan potensi diri. Kisah masa kecil merupakan hal yang paling mengesankan, apalagi jika mengenai kenangan indah seorang anak terhadap kedua orangtuanya. Kehidupan keluarga berperan besar dalam membangun pribadi seorang anak. Di sanalah bermula proses pembudayaan, sehingga melahirkan pribadi yang baik, budi pekerti 
luhur, dan taat beragama. Keluarga pula yang membentuk seseorang menjadi warga yang baik, dan menghayati keragaman sebagai sumber kekuatan peradaban bangsa.

Novel Anak Sejuta Bintang sejatinya mengisahkan priode pembudayaan seorang anak bernama Ical, dalam novel tersebut memuat nilai-nilai luhur yang perlu dipetik oleh generasi penerus, agar menjadi anak yang berbudi dan berbakti kepada orangtua. Hal yang serin $g$ dilupakan bahwa program untuk kesejahteraan itu dimulai dari masyarakat paling kecil yaitu keluarga, dan hal ini tergambar jelas dalam novel Anak Sejuta Bintang. Di dalamnya tergambar kasih sayang, menghormati, simpati, empati. Mengenai persahabatan dan kasih sayang keluarga sangat Rental digambarkan dalam novel tersebut Bakrie dan Roosianah sebagai orangtua dari Ical berhasil menciptakan rutnah dan keluarga menjadi Sekolah terbaik untuk menanamkan kejujuran, keberanian dan kesiapan menghadapi keberagaman. Keteladanan dalam keluarga terutama orangtua, kerja keras, ketekunan, ketelitian dan keuletan hidup serta pergaulan sehat di masa-masa sekolah dapat menjadi modal positif, hal tersebut tergambar jelas dalam novel ini.

Sejak kanak-kanak, Ical sering mendengar kata-kata bijak dari ayahnya, Achmad Bakrie, seperti "memberi sesuatu yang kita senangi kepada orang lain itu selalu membuat kita bahagia" maka tidak mengherankan jika di usia Ical yang masih belia, ia mampu berkata kepada temannya "menolong teman itu bukan hal yang aneh. Tapi harus"

Ical dibiasakan sang Ayah mengagumi taburan bintang di langit yang menerangi kegelapan. Sebab itu, sewaktu lulus Sekolah Rakyat, ia berkata kepada ayahnya, "bintang yang paling terang dalam kehidupan Ical adalah Papa dan Mama. Berkat cahaya cinta Papa dan Mama, Ical bisa menemukan cahaya-cahaya bintang lainnya".

Alur cerita novel Anak Sejuta Bintang sangat inspiratif, karena novel tersebut mampu menginspirasi peneliti bahwa kesuksesan tidak ditentukan oleh kekayaan dan status, tetapi berkat peran penting pendidikan keluarga, yaitu dengan pola asuh yang benar dan tepat yang mengedepankan potensi Tuhan, alam, keluarga dan lingkungan. Tokoh-tokoh yang berperan di dalamnya adalah Manusia- manusia yang bijak, penuh cinta, taat beragama, tekun, jujur, berani, sabar, dermawan, penuh motivasi, sifat keayahan dan keibuan sangat kental serta penuh keteladanan diperankan yang dituturkan secara sederhana dan indah.

\section{Rumusan Masalah}

Rumusan peneliian ini adalah sebagai berikut.

Bagaimana sikap tokoh terutama yang berkaitan dengan aspek bijaksana, kasih sayang, tidak putus asa, disiplin, memelihara persahabatan, dermawan, dan suka menolong.

\section{Tujuan Penelitian}

Tujuan yang ingin dicapai dalam penelitian ini adalah untuk mendeskripsikan nilai moral yang terkandung dalam novel Anak Sejuta Bintang karya Akbal Nasery Basral yang ditinjau dari moral baiknya.

\section{Landasan Teori}

\section{Hakikat Kesusastraan}

Effendy (dalam Badudu, 2003: 5) mengemukakan "kesusastraan ialah ciptaan manusia dalam bentuk bahasa lisan maupun tulisan yang dapat menimbulkan rasa bagus."

Sesuai dengan pernyataan tersebut yang dimaksud bagus adalah rasa keindahan yang dapat dirasakan oleh pembaca ketika membaca sebuah karya sastra, tidak seperti membaca karya-karya lainnya di luar sastra pembaca tidak akan menemukan rasa indah ketika 
membacanya. Jadi, karangan yang bersifat buku pelajaran atau yang bersifat laporan tidaklah termasuk dalam kesusastraan karena tidak menimbulkan rasa bagus atau rasa indah.

Kekhasan pemakaian bahasa yang menimbulkan keindahan inilah merupakan letak perbedaan antara sastra dan karangan-karangan non sastra, dalam hal ini Semi (1988 : 15) menyatakan " kesusastraan adalah pengucapan atau tulisan yang tergolong ke dalam kreatif imajinatif dan berlainan dengan tulisan-tulisan dalam surat kabar informatif- persuasif."

Masyarakat modern selalu berubah, hal ini ditandai dengan adanya kemajuan tekhnologi pengangkutan dan komunikasi, sebenarnya dalam masyarakat modern kesusastraan dapat berkembang dengan subur dan nilai-nilainya dapat dimanfaatkan oleh umum. Berkaitan dengan ini Sugono (2002: 233) mengemukakan bahwa "kesusastraan sendiri mengandung potensipotensi ke arah keluasan kemanusiaan dan semangat hidup semesta."

Karya sastra yang berhasil terkandung ekspresi total pribadi manusia meliputi tingkat pengalaman biologi, sosial, intelektual dan religius. Nilai-nilai seperti itu sangat diperlukan oleh masyarakat modern. Dari dulu sampai sekaranag karya sastra dapat dipakai untuk mengembangkan wawasan berpikir bangsa. Ini berarti wartawan ikut serta dalam mencerdaskan bangsa. Sastrawan dapan memberikan tanggapan dan penilaian terhadap apa yang terjadi dalam masyarakat modern.

\section{Hakikat Fiksi}

Abrams (dalam Nurgiyantoro 2002: 2) menyatakan bahwa" fiksi merupa-kan karya imajinatif yang isinya tidak menyaran pada kebenaran sejarah." Dengan demikian, karya fiksi menyaran pada suatu karya yang menceritakaan sesuatu yang bersifat rekaan, khayalan, sesuatu yang tidak ada dan terjadi sungguh-sungguh sehingga tidak perlu dicari kebenarannya pada dunia nyata.

Fiksi menceritakan berbagai masalah kehidupan manusia dalam interaksinya dengan lingkungan dan sesama interaksinya dengan diri sendiri, serta dengan interaksinya dengan Tuhan. Dalam hal ini Nurgiyantoro (2002 : 3) mengemukakan bahwa "fiksi merupakan hasil dialog, kentemplasi dan reaksi pengarang terhadap lingkungan dan kehidupan."

Fiksi menawarkan model-model kehidupan sebagaimana yang diidealkan oleh pengarang sekaligus menunjukkan sosoknya sebagai karya seni yang berunsur estetik dominan. Membaca sebuah karya fiksi berarti menikmati cerita, menghibur diri untuk memperoleh kepuasan batin. Menurut Wellek \& Werren (dalam Nurgiyantoro, 2003: 3) "betapapun saratnya pengalaman dan permasalahan kehidupan yang ditawarkan, sebuah karya fiksi haruslah tetap merupakan cerita menarik, tetap merupakan bangunan struktur koheren dan tetap mempunyai tujuan estetik".

\section{Hakikat Novel}

Novel yang diartikan sebagai memberikan konsentrasi yang lebih tegas dengan roman yang diartikan rancangannya lebih luas mengandung sejarah perkembangan yang biasanya terdiri dari beberapa fragmen yang patut ditinjau kembali. Adanya definisi demikian lantaran sekitar tahun 1950-an novel-novel Indonesia ditulis oleh Pramudya Ananta Toer, Mochtar Lubis, dan Achdiat memang bersifat demikian, sedangkan roman dalam pengertian di atas terdapat dalam buku -buku Balai Pustaka lama. Jakop Sumarjo (dalam Semi, 1998: 33 ) " Novel yang lebih memusat dan roman yang lebih luas sebenarnya terdapat pada istilah novel maupun roman". Maka ditegaskan tidak perlu dibedakan antara novel dan roman, dalam pengertian 
novel tercakup pengertian roman yang sering digunakan pada masa sebelum perang kemerdekaan.

The American College Dictionary (dalam Tarigan 1984: 167) dapat kita jumpai keterangan bahwa "novel adalah suatu cerita prosa yang fiktif dalam panjang yang tertentu, yang melukiskan para tokoh, gerak serta adegan kehidupan nyata yang representatif dalam suatu alur atau suatu keadaan yang agak kacau atau kusut."

Tarigan (1984: 166) memberi pengertian bahwa "kata novel berasal dari kata latin novellas yang diturunkan pula dari kata navies yang berarti baru." Dikatakan baru karena bila dibandingkan dengan jenis-jenis sastra lainnya seperti puisi, drama dan lain-lain, maka jenis novel ini muncul kemudian.

Novel merupakan bentuk karya sastra yang lebih digemari oleh pembaca daripada karya sastra lainnya, cerita dalam novel yang disajikan dengan bahasa yang mudah dipahami mampu menarik minat pembaca. Pusporodjo (1999: 11) mengemukakan bahwa:

"novel adalah cerita, dan cerita digemari manusia sejak kecil. Dan tiap hari manusia senang pada cerita, entah factual, untuk gurauan atau sekedar ilustrasi dalam percakapan. Bahasa novel juga bahasa denotatif, tingkat kepadatan dan makna gandanya sedikit. Jadi novel mudah dibaca dan dicernakan. “

\section{Hakikat Intrinsik dan Ekstrinsik}

Nurgiyantoro ( 2002: 23 ) menjelaskan bahwa "Unsur intrinsik adalah unsur-unsur yang membangun karya sastra itu sendiri. Unsur-unsur inilah yang menyebabkan karya sastra hadir sebagai karya sastra, unsur-unsur yang secara faktual akan dijumpai oleh pembaca sastra."

Menurut Semi (1988: 35) "Struktur dalam (intrinsik) adalah unsur-unsur yang membentuk karya sastra tersebut seperti penokohan dan perwatakan, tema, alur (plot), pusat pengisahan, latar dan gaya bahasa."

Menurut Esten (2000 : 20) mengatakan bahwa "segi intrinsik ialah yang membangun ciptasastra itu dari dalam. Misalnya hal-hal yang berkaitan dengan struktur. Seperti alur (plot), latar, pusat pengisahan dan penokohan,kemudian juga hal-hal yang berhubungan dengan tema dan amanat."

Nurgiyantoro ( 2002: 23 ) menjelaskan bahwa Unsur ekstrinsik adalah unsur-unsur yang berada di luar karya .sastra itu, tetapi secara tidak langsung mempengaruhi bangunan atau system organism karya sastra. Atau secara lebih khusus ia dapat dikatakan sebagai unsur-unsur yang mempengaruhi bangun cerita sebuah karya sastra namun sendiri tidak ikut menjadi bagian di dalamnya."

\section{METODE PENELITIAN}

Analisis pada penelitian ini menggunakan penelitian kualitatif, yaitu suatu prosedur yang menghasilkan data deskriptif berupa kata-kata tertulis atau lisan atau prilaku orang yang diamati. Pendekatan dalam penelitian ini adalah pendekatan moral dengan analisi isi novel. Data yang dikumpulkanpun berupa kata atau kalimat.

Dengan pendekatan moral ini penulis melihat seberapa jauh sebuah karya sastra itu memiliki unsur moral. Bertolak dari asumsi dasar bahwa kehadiran teks sastra di kalangan pembaca sebagai upaya meningkatkan harkat dan martabat manusia sebagai makhluk berpikir, berasa,berbudaya, dan beragama. Moral dalam pemahaman filsafat sebagai suatu rumusan konsep masyarakat mengenai standarisasi kebaikan dan keburukan. Untuk itu, moral sebagai 
suatu norma dalam kehidupan masyarakat mempunyai peran penting menata interaksi sosial sesama masyarakat (Hanum, 2012 : 86).

Penelitian ini dilakukan pada aspek moral tokoh utama dalam novel Anak Sejuta Bintang karya Akmal Nasery Basral. Menurut Hanum (2012 : 86) teoritis kriteria moral mencakup: Kreasi sastra yang berkualitas sempurna, Penentuan data buruk dan data baik berfokus pada substansi cerita, Sebagai sarana didaktik,

Menurut Hanum (2012 : 87) dalam pengorganisasian, penyajian dan penganalisisan data, teknik penelitian moral mencakup: Di dalam penelitian teks sastra yang paling utama yang harus diamati adalah substansi isi cerita berupa falsafah hidup, pemikiran, dan pesan-pesan yang ada di dalam karya sastra. Selanjutnya aspek didaktik perlu mendapat sorotan kritis dari peneliti. Hal ini dapat diamati pada penelaahan data perwatakan tokoh-tokoh sentral. Aspek moral pada teks sastra sangat berbeda dengan pengungkapan aspek moral secara eksplisit dalam buku teks budi pekerti, sehingga penyorotan aspek moral dalam teks sastra secara kaku akan mengorbankan nilai-nilai kesusastraan, dan Penggambaran konsep moral secara dan berbobot pada teks sastra dapat saja berlangsung, tetapi tidak akan bermanfaat besar apabila para pembaca tidak mampu memahaminya secara tepat. Penentuan berfaedah atau tidaknya sebuah teks sastra akan sangat bergantung pada resepsi para pembaca.

Populasi dalam penelitian ini adalah novel Anak Sejuta Bintang karya Akmal Nasery Basral. Novel ini terbit pada tahun 2012.

Sampel penelitian difokuskan pada teks sastra berdasarkan adegan yang diperankan masing-masing tokoh yang menjadi representasi muatan nilai moral. Penentuan sampel dalam penelitian dilakukan secara purposive atau terarah pada teks sastra yang mencerminkan nilainilai moral melalui adegan-adegan yang terdapat yang mencakup dimensi moral baik.

\section{PEMBAHASAN}

Novel Anak Sejuta Bintang karya Akmal Nasery Basral merupakan gambaran novel yang kaya akan nilai moral, terutama moral baik. Moral baik yang terkandung dalam novel Anak Sejuta Bintang karya Akmal Nasery Basral adalah bijaksana, perhatian dan kasih sayang, tidak putus asa, memelihara persahabatan, disiplin, dermawan, suka menolong dan ramah tamah. Dapat dikatakan bahwa novel Anak Sejuta Bintang karya Akmal Nasery Basral memiliki aspek moralitas sebagai gambaran aspek moral baik, di antaranya :

\section{Aspek Bijaksana}

Aspek bijaksana dapat dilihat pada kutiipan berikut ini.

"Mendadak keheningan yang ganjil terjadi antara Bakrie dan Le Soen Tjiang, Meski di sekeliling mereka suasana begitu riuh. Jangan-jangan lumah saya yang bawa ciong bagi Pak Bakeli. Tenang, Pak. Meski tak sedikit orang yang mempercayai hal seperti itu,saya tidak berpikiran bahwa ada rumah yang bawa ciong atau hokkie. Bakrie menepuk lembut pundak Le Soen Tjiang. Bagi saya, semua tergantung pada ikhtiar orang yang ada di rumah itu dan kehendak Tuhan. "(ASB/2011/46).

"Pada mulanya, proses kelahiran anak ketiga mereka berjalan mulus, lancer, tanpa rintangan berarti. Dokter Ghulam dan Suster Tuti bekerja dengan sigap. Bayi yang mereka nantikan lahir dengan selamat. August Alamsjah, begitu nama mereka sepakati untuk putra ketiga mereka. Tetapi sekali lagi, Tuhanlah yang menentukan segalanya. Malaikat maut menjemput Alamsjah. Roosianah terpukul, bagai kehilangan seoaruh iiwanva. Bakrie 
mendesah. Yang tabah Ma. kita hanva bisa berencana. Roosianah tertegun mengangguk pasrah. Segala yang datang dari Allah, tutur Bakrie lagi, niscaya kembali ke dalam dekapan cinta-Nya. "(ASB/2011/60).

"Mata Milun berbinar-binar melihat orang kaya dari Jakarta di depannya itu sangat menikmati pisang goring buatan Ibunya. Milun, Tegur Bakrie. Jangan berkecil hati. Tidakada seseorangpun yang tiba-tiba saja menjadi kaya raya. Semua butuh perjuangan, keuletan dan ketekunan. Jangan patah semangat. Siapa tahu kelak kamu temukan resep membikin kue yang enak lalu kamu titipkan ke tempat-tempat yang ramai dikunjungi orang. Setiap ada keinginan untuk maju Allah pastimembantu. “(ASB/2011/79).

"Kelasmu bagaimana? Nggak enak. Panas. Namanya juga kelas sementara. Begitu gedung bam selesai dibangun, Ical pasti pindah. "(ASB/2011/118).

"Cermin itu terletak di atas meja tepat berada di depan Ical. Bakrie mengambil cermin itu dan menahan sejajar dengan wajah Ical. Setelah tertegun sesaat, Ical menggeleng. Lewat cermin, peci itu terlihat bertengger pas di kepala, tapi ia lebih memilih sepeda. Tidak maul Ical melepaskan peci. Roosianah berusaha membujuk Ical. Nak sebentar lagi kamu masuk Sekalah Rakyat. Nanti kamu butuh peci untuk salat dan mengaji. Ical menatap ibunya dengan tatapan sendu. Ma teman-teman di Sekolah sudah punya sepeda, semuanya, kecuali aku!. fya. Bujuk Bakrie. Nanti kita belt sepeda. Sekarang kita beli peci dulu. "(ASB/2011/156).

"Ical kebingungan. Aku pilih yang mana, Pa? la berada di sebuah dunia yang segala sepeda tersedia, tinggal pilih dan tunjuk sepeda mana yang sesuai dengan selera. Bayangan teman-temannya berkelebi kepala. la ingin memiliki sepeda mini yang berbeda yang belum dimiliki oleh teman-teman dan sanak kerabatnya. Pilihlah sepeda yang sesuai dengan kebutuhanтu, jawab Bakrie.Maksud Papa? Jangan memilih sesuatu hanya karena kamu suka. Bolehjadi kamu senang, tapi kalau itu terlalu besar, tetap saja tidak berguna." (ASB/2011/160)

"Cal! ujar Roosianah dengan lembut tapi tegas. Tadi Papa sudah bilang setelah Ical naik kelas dua. Mama setuju, karena kalau sudah kelas dua umurmujuga sudah tujuh tahun. Latihan bela diri itu butuh tulang dan otot yang kuat. fya. Ma, katanya sembari menyembunyikan rasa kece-wa. Tapi janji ya , Pa! Insyaallah. Insyaallah? Ical kembali merajuk. Yang pasti dong, Pa. Bakrie menatap Ical dengan lembut.

"Kita tidak boleh memastikan sesuatu, Cal. Nabi Muhammad mengajari kita mengatakan Insyaallah. Artinya? Jika Allah mengizinkan. Sebagai manusia, kita hanya bisa merencanakan. Yang bisa memastikan semuanya Cuma Allah." (ASB/2011/157).

"Memberi sedekah itu tidak boleh ada kata tetapi. Harus rela harus ikhlas. Tangan kanan memberi tangan kiri merahasiakan. "(ASB/2011/272).

"Melihat ayahnya memejamkan mata dan terdiam beberapa diri. Ical mulai ketakutan, Roosianah juga terdiam. Dia merasa bersalah karena tak bisa mencegah Ical memberikan sesuatu yang bukan haknya kepada orang lain. Maaf, Pa, kata Ical agak terbata, "Ical tidak minta izin. Tidak ada perlu yang dimaafkan, Nak. Jawab Bakrie. Papa tidak marah? tanya Ical lagi. Bakrie menarik Ical ke dalam pelukan. Untuk apa Papa marah? Setiap orang yang datang ke rumah kita, pasti lebih besar dari Ingga? Bakrie sambil melirik sang anak yang melamun. Kok diam tents, Cal? Ical bergeming tak menjawab. Posisi kedua dalam ujian akhir itu sama sekali bukan hal yang jelek. Lanjut Bakrie karena mengerti penyebab kegundahan putra asulungnya." 
"Ical minta maaf karena telah mengecewakan Papa dan Mama, katanya dengan mata berkaca-kaca. Siapa bilang Papa dan Mama kecelva?sahut Bakrie. Papa tahu kamu sudah belajar keras, Mama sering menceritakan keuletan dan ketekunanmu. Kamu sudah berusaha sekuat daya, itulah yang sesungguhnya membanggakan dan membahagiakan hati Papa. Betul, Cal, imbuh roosianah, Mama tidak kecewa. Ingat, Nak, ada kekuatan di luar diri kita yang lebih menentukan, kata Bakrie sambil menoleh kepada Ical. “

"Papa tidak melarang kamu sedih karena hasil ujian. Sedih itu lumrah. Tetapi sedih yang secukupnya saja. Menjadi juara dua itu bukan hal yang buruk. Kalau diibaratkan perusahaan, kondisi keuanganmu tidak minus seperti waktu Papa bangkrut. Ical menggigit bibir, menarik nafas dalam-dalam seakan ingin membuang sebuah gunungyang membebani dada. Jangan sampai kesedihan itu membuat Icaljauh dari adik-adik, mengurung diri. Ical harus menunjukkan bahwa sebagai anak tertua, sebagai kakak sulung. Ical bisa menjadi contoh ketegaran bagi adik-adik. " (ASB/2011/394).

"Jadi dengan namamu itu. Papa dan Mama ingin Ical menjadi pemimpin yang pemberani, laki-laki yang pemberani, pemimpin yang berjiwa pelindung, tak akan membiarkan dirinya dikuasai kesedihan terus-menerus. Bukan kesedihan yang menguasai dirinya, tapi dirinya yang harus bisa menguasai kesedihan. Sedih itu boleh, manusiawi, tapi jangan terlalu lama. Kalau kita anggap suasana gembira itu seperti siang hari yang cerah dan terang, maka kesedihan adalah suasana gelap. Kita tidah boleh terlalu lama berada di dalam gelap, Cal kamu tahu mengapa? Ical kembali menggeleng. Karena kalau kita berdiri terlalu lama di dalam gelap, bayangan kitapun akan pergi meninggalkan kita. "(ASB/2011/ 395).

"Ical menatap wajah sang ayah. Basil ujian ini benar-benar membuat Ical sedih, Pa. Papa tahu. Tapi seperti Papa bilang, sebetulnya hasil ujianmu tidak buruk, bahkan masih jauh di atas nilai rata-rata murid lain. Semua menjadi terasa buruk karena Ical sendiri yamg mengundang kesedihan itu, Papa tahu karena sifatmu yang selalu ingin sempurna. fya, kan? Ical mengangguk, Sekarang coba Ical lihat dengan cara lain. Kamu pernah berlatih Judo ditangani langsung Ferry Sonneville, yang kini menjadi bintang Indonesia dalam merebut piala Thomas. Ical pernah menyanyi langsung di depan Bung Karno, dan mendengar pidato beliau yang pernah Ical bilang sendiri ke Papa bahwa pidato itu bukan cuma membuat semangatmu berkobar, tetapi membuatmu lebih mengerti persoalan bangsa. Berapa banyak anak Indonesia yang pernah langsung mendengarkan kata-kata Bung Karno dan berdiri di depan beliau, Cal? Sedikit sekali, han?” (ASB/2011/396).

"Belum lagi guru-gurumu di Sekolah yang menjadi bintang penerangmu sehari-hari. Mereka adalah bintang yang menemani kamu menemukan sesuatu, dari yang semula tidak tahu menjadi tahu, dari tidak mengerti menjadi mengerti. Ical kembali menganggukanggukan kepala. Jangan lupakan guru mengajimu. Ustadzah Rohime. Meskipun beliau bukan orang terkenal seprti guru-gurumu yang lain, tapi karena kerja kerasnya kamu bisa memahami betapa indahnya cahaya Ilahijika sudah menerangi hati. “(ASB/2011/396).

"Sekarang Papa mau tanya Cal, satu pertanyaan saja. Tapi coba Ical pikirkan baik-baik sebelum menjawab, ini bukan benar atau salah, Papa hanya ingin mendengar jawaban yangjujur dari hatimu. Dengan semua bintangyang sudah menerangi hidupmu selama ini, dan banyak dari bintang-bintang yang luar biasa itu tak sempat dinikmati cahayanya oleh anak-anak lain di negeri ini, pertanyaan Papa, apakah kamu masih merasa pantos untuk bersedih hati berlama-lama? Ya, Pa, Pikirkan dulu nak, ini bukan soal Sekolah yang harus dikumpulkan, Papa tahu salah satu sikapmu adalah serba ingin cepat, tidak sabaran. Sama 
seperti Papa. Itujuga ciri-ciri orangyang selalu ingin semuanya serba sempurna. Tapi sekarang coba pikirkan dulu dengan tenang, benar-benar dengan tenang, apakah bersama sejuta bintang dengan cahaya cemerlangyang melintas dalam hidupmu sekatrang. Ical masih merasa pantos bersedih hati? Bayangkan bagaimana anak-anak yang hanya ingin melihat Bung Karno dari dekat sampai Hants mengorbankan nyawa mereka sedini itu? bayangkan anak-anak yang Ical kasih apel dan anggur di hari lebaran beberapa tahun lalu?bayangkan juga anak-anak gang Ampiun yang meskipun Ical lihat hebat dalam bermain sepak bola, tapi pernahkah Ical benar-benar Ical pikirkan kehidupan mereka sehari-hari yang mesti mencari nqfkah untuk segenggam beras di tengah kerasnya kehidupan pasar?"(ASB/2011/398).

Pada kutipan-kutipan di atas menggambarkan bahwa Pak Bakrie merupakan sosok orang yang bijaksana.

\section{Aspek Kasih Sayang}

Aspek Kasih saying dapat dilihat pada kutiipan berikut ini.

"Cap Lak Meh di lapangan Meester Cornells ternyata lebih ramai. Sepanjang mata memandang , yang Nampak manusia berjubel-jubel, lampion warna-warni, hiasan kaligrqfi, dan pedagang makanan yang riuh menawarkan dagangannya. la pun segera mencekal tangan Ical, khawatir terlepas dan tenggelam di tengah kerumunan. Col, kamu harus tents memegang tangan Papa. Ujar Bakrie dengan suara yang sedikit bergetar. (ASB/2011/37).

"Setibanya di rumah, kelopak mata Ical sudah tidak mau terbuka. Aduh kasihan anak Mama. Ujar Roosianah sambil mengambil Ical dari gendongan suaminya. Pasti Ical kelelahan. "(ASB/2011/53).

"Bakrie mengelus perut isterinya. Kehamilan mama makin besar, tidak boleh terlalu cemas. Pikirkanyang bagus-bagus saja. "(ASB/2011/55).

Wah mama jadi tidak sabar untuk melihat istana Cipanas dari dekat. Selama ini Cuma dengar-dengar saja. Kapan kita liburan, Pa? Bakrie tersenyum. Papa pastikan dulu tempatnya aman dan nyaman buat mama dan anak-anak. "(ASB/2011/59).

"Sakit, Ma," kata Ical sambil memegang dada kirinya. "Coba ambil nafas dengan tenang, jangan buru-buru, jawab Roosianah sambil mencontohkan cara menghirup nafas yang lebih tenang. Ical mencobanya menarik nafas, menahannya beberapa jenak, dan memegang dadanya. Ada geletar nyeri yang menjalar ke dadanya. Bagaimana sekarang? lanjut Roosianah. Masih, jawab Ical sambil mengernyitkan keningnya. pusingjuga. Ya sudah, kamu naik ke tempat tidur dulu, istirahat. Jangan main lagi. Mudah-mudahan nanti sakitnya hilang. "(ASB/2011/62).

Kita duduk-duduk di kamarya.Buju k Bakrie. Ical menggeleng, Tidak mau, Ical belum ngantuk Odijuga. Kalau di luar, nanti Ical dan Odi kedinginan, lalu sesak nafas lagi. Kalau di dalam, papa akan bercerita tentang asal mula bintang." (ASB/2011/82).

"Mama juga pulang? Tanya Ical menoleh kea rah ibunya yang sedang memasukan roti tawar berlapis mentega dan butiran coklat ke dalam kotak makanan untuk bekal Ical di Sekolah. Mama akan menunggu di Sekolah hingga kamu pulang. Setelah mengantar Papa. Pak Jayadi akan menjemput kita. "(ASB/2011/99).

"Bintang yang paling terang dalam hidup Ical adalah Papa dan Mama. Karena cahaya cinta Papa dan Mama sehingga Ical bisa menemukan cahaya bintang-bintang lainnya. “(ASB/2011/399). 
Pada kutipan-kutipan di atas menggambarkan bahwa Pak Bakrie dan Roosianah merupakan sosok orang tua yang penuh rasa kasih sayang terhadap anak-anaknya dan Ical merupakan sosok seorang anak yang sangat menyayangi kedua orang tuanya.

\section{Aspek Tidak Putus Asa}

Aspek Tidak Putus Asa dapat dilihat pada kutipan berkut ini. .

"Sama sekali nggak kelihatan kalau bapak pernah bangkelut. Itu karena saya dan isteri saya tidak ingin orang lain tahu, pak, jawab bakrie sambil menghela nafas dalam-dalam. Padahal, kalau diungkapkan dengan air mata, sudah tidak ada lagi air mata yang bias menetes dari pelupuk mata kami saking beratnya beban hidup kami. Belum lagi utang yang menumpuk di mana-mana. Bakrie menarik nafas panjang lagi. Tapi saya sudah bertekad, apapun yang terjadi, saya harus bangkit dan lebih berhasil lagi dari sebelumnya, Pak" (ASB/2011/46)

"Yang hebat itu tantemu. Катu sih biasa-biasa saja, ujar Adian sambil berlari cekikikan. Ical tak menanggapi gurauan Adian. Ia hanya mengepalkan dan bertekad di dalam hati. kelak aku pasti bisa memukul bola kasti dengan baik” (ASB/2011/190).

"Sewaktu kamu berumur dua tahun, Cal, .perusahaan Papa, Bakrie \& Brothers, bangkrut. Habis. Uang tak ada, hutang segunung. Semua orang menganggap perusahaan ini sudah tidak ada. Mati. Papa juga sempat berpikiran begitu. Topi kemudian Papa berpikir, kalau Papa yang berpikir perusahaan ini akan mati, maka perusahaan ini pasti akan mati betulan. Jadi, Papa mulai lagi semuanya dari nol. "(ASB/2011/393).

"Ical berdiri dan menengadah ke langit, ketika tim kami kalah dari anak-anak Gang Ampiun, Cik Darmasti bilang kami tidak boleh menyerah apalagi putus asa. Kami telah berlatih, tapi takdir menentukan kenyataan yang tak sesuai harapan kami. Dan, kami tidak boleh berlama-lama menghukum diri sendiri dengan kesedihan. “(hal;399).

"Ical tidak akan menghukum diri sendiri yang tenggelam dalam kesedihan. Ical harus bangkit. Ical harus menjadi bintang Waluku yang bersinar penuh makna,” (ASB/2011/399).

"Sewaktu kamu berumur dua tahun, Cal, .perusahaan Papa, Bakrie \& Brothers, bangkrut. Habis. Uang tak ada, hutang segunung. Semua orang menganggap perusahaan ini sudah tidak ada. Mati. Papa juga sempat berpikiran begitu. Topi kemudian Papa berpikir, kalau Papa yang berpikir perusahaan ini akan mati, maka perusahaan ini pasti akan mati betulan. Jadi, Papa mulai lagi semuanya dari nol. “(ASB/2011/393).

"Ical berdiri dan menengadah ke langit, ketika tim kami kalah dari anak-anak Gang Ampiun, Cik Darmasti bilang kami tidak boleh menyerah apalagi putus asa. Kami telah berlatih, tapi takdir menentukan kenyataan yang tak sesuai harapan kami. Dan, kami tidak boleh berlama-lama menghukum diri sendiri dengan kesedihan. "(hal;399).

"Ical tidak akan menghukum diri sendiri yang tenggelam dalam kesedihan. Ical harus bangkit. Ical harus menjadi bintang Waluku yang bersinar penuh makna,” (ASB/2011/399).

Pada kutipan-kutipan di atas menggambarkan bahwa Pak Bakrie merupakan sosok orang yang tidak mudah putus asa. Dan Ical merupakan sosok anak yang tidak mudah putus asa dan selalu bangkit dari masalah.

\section{Aspek Disiplin}

Aspek Disiilin dapat diihapa pada kutipan berikut in.

"Roosianah duduk di sofa, di samping suaminya, dan tersenyum kepada suaminya yang tengah menyesap air dengan khidmat. Papa suka pesta kan,? Waktunya tidak tepat, Papa 
sedang menyusun rancangan kerjasama dengan sebuah perusahaan Jerman. “(ASB/2011/33).

"Harus disiplin. Semua adajadwalnya. Waktu belajar, waktu cari gambir, waktu jualan kue, waktu main. "(ASB/2011/147).

"Ical harus ulangi semua kata-katamu barusan kepada Mama. Semua, jangan sampai ada yang terlewat. Karena pasti hal itu akan membuat Mama bahagia, bahwa seluruh disiplin dan ketegasanyang Mama ajarkan selama ini sudah mulai menunjukkan hasil. “(ASB/2011/399).

"Ini bogus , Pak, ujar Hasan sambil menunjuk gambar seorang pendekar sedang memutar tombak di atas pentas. Ajak aja Ical nonton, Pak. Paling sebentar lagi sandiwara dimulai. Mulainya saja pukul Sembilan, pasti selesainya bisa tengah malam. Bagaimana bisa ditonton anak umur tiga tahun?"(ASB/2011/51).

Pada kutipan-kutipan di atas menggambarkan bahwa Pak Bakrie merupakan sosok orang disiplin dalam membagi waktu dan orang yang selalu mengajarkan anak-anaknya untuk disiplin. Dan Roosianah adalah sosok seorang ibu yang disiplin dalam mendidik anakanaknya.

\section{Aspek Memelihara Persahabatan}

Aspek Memelihara Persahabatan dapat dilihat pada kutipan berikut ini.

"Papa punya rencana kongsi dengan Pak Ning? Ah, tidak perlu, Ma. Persahabatan bisa abadi, bisnis belum tentu. Dulu Papa sempat berdebat sengit soal kongsi dagang dengan Hasjim. Kata Papap, Hasjim, kamu pintar saya juga pintar, karena fata sama-sama pintar, lebih baik kita tidak menjalin kongsi dagang. Persahabatan kita biaspecah. "(ASB/2011/56).

"Di Stasiun ini, sebelum kamu lahir, papamu pernah menjemput Om Hasjim Ning yang punya pabrik mobil itu. Mengapa ayahmu akrab dengan Om Hasjim? Dagang. Jawab Ical spontan. Bukan, karena mereka berteman sejak lama. Sejak masih sama-sama kecil di Lampung. Ical tahu maksud Mama? Ical menggelengkan kepala. Menjaga hubungan pertemanan, itu yang selalu dilakukan oleh Papamu." (ASB/2011/125).

Berdasarkan kutipan di atas, Pak Bakrie merupakan seseorang yang berkarakter sangat memelihara hubungan persahabatan.

\section{Aspek Dermawan}

Aspek Dermawan dapat dilihat pada kutipan berikut ini.

"Setelah mereka jauh dari lapak Cici, Bakrie berbisik kepada Hasan "Yang lima butir buat kamu bawapulang ke rumahmu, San. "(hal 49).

"Itu jas kesukaan Papa kan? Tanya Roosianah tidak lama setelah Soesilo pergi. Bakrie mengangguk, kenapa, Ma? Ya tidak apa-apa, jawab Roosianah. Memberi sesuatu yang kita senangi kepada orang lain itu selalu membuat hati kita bahagia. Rezeki kita pasti akan bertambah jika kita bisa lebih ikhlas.” (ASB/2011/132).

"Anak-anak kampong itu seolah takpercaya ketika melihat Ical membawa talang berisi apel dan anggur. Ini, kata Ical kepada anak yang terdekat sambil menyerahkan buah-buahan itu. Bagikan dengan adilya. "(ASB/2011/269).

Berdasarkan kutipan di atas menunjukan bahwa Bakrie sesorang yang mempunyai karakter moral yang suka memberi dan senang memberi kepada orang lain. Dan Ical juga merupakan sosok anak yang suka memberi. 


\section{Aspek Suka Menolong}

Aspek Suka Menolong dapat dilihat pada kutipan berikut ini. .

"Tidak punya jas itu bukan punya dosa besar, Soes. Saya punya jas yang bagus untukmu. Sosesilo semakin salah tingkah. Aduh, sayajadi tidak enak, Pak. Saya ke sisni buat silaturahmi dan mohon doa Pak Bakrie, seperti saran mertua saya. Tidak apa-apa. Talang menolong itu sama pentingnya dengan keuletan dan ketekunan, Soes. Tolong-menolong tanpa pandang bulu, asal-muasal, atau hubungan kekerabatan. "(ASB/2011/131).

Berdasarkan kutipan di atas Bakrie adalah orang yang menjunjung tinggi sikap menolong karena baginya itu mampu membina hubungan kekerabatan.

\section{Aspek Suka Menolong}

Aspek Suka Menolong dapat dilihatpada kutipan berikut ini .

"Tiba-tiba terdengar suarayang membuyarkan konsentrasi mereka. Akhirnya Pak Bakeli datang juga. Bogus, bogus! Bakrie menoleh dan segera menyambut tangan penyapanya Pak Soen Tjiang. Katanya. Terima kasih sudah mengundang saya. Ternyata memang sangat menarik. (ASB/2011/44).

"Nasah penjaga villa . tergopoh-gopoh menghampiri Bakrie. Bahunya yang bidang tampak berguncang-guncang seirama ayun langkah yang gesit dan penuh tenaga. Bibimya terns menerus mengulum senyum. Mukanya berseri-seri, rambutnya acak-acakan dan basah oleh keringat. Begitu tiba di hadapan Bakrie, ia menyalami dengan tubuh setengah membungkuk dan menarik telapak tangan Bakrie kea rah bibirnya, seolah hendak mencium. Tapi Bakrie manarik dengan lembut."

"Punteun Pak Bakrie. Masih ada lagi yang man diturunkan dari mobil? ujar Nasah sembari tak henti-henti mengulum senyum. Maap, saya tadi di belakang waktu Bapak datang. Bakrie tersenyum ramah. Eh, Mang Nasah. Kumaha damang?”(ASB/2011/74).

Berdasarkan kutipan-kutipan peristiwa di atas mencerminkan sosok Bakrie yang sangat bersikap ramah terhadap orang lain dan menghormati sesorang yang lebih tua, tidak memandang status sosial sesorang.

\section{Kecenderungan Unsur Moral dalam Novel Anak Sejuta Bintang Karya Akmal Nasery Basral}

Kecenderungan moral baik yang dapat peneliti temui dalam novel Anak Sejuta Bintang karya Akmal Nasery Basral dari keseluruhan temuan nilai moral adalah nilai moral baik bijaksana dan kasih sayang.

Nilai moral baik bijaksana yang mencapai $42 \%$ temuan. Peneliti temukan ungkapanungkapan bijaksana yang ditampilkan oleh pengarang melalui tokoh Bakrie sebagai tokoh utama, Pengarang di sini menegaskan bentuk kebijaksanaan dengan bahasa sastranya, bahwa dalam hidup seseorang ada saatnya akan mengalami kegagalan, namun janganlah kegagalan tersebut melahirkan kobaran kesedihan hingga memadamkan semangat hidup. Sesuatu yang kita harapkan tidak selamnya menjadi kenyataan. Kesedihan akibat dari kegagalan satu hal tidak seharusnya menjadi kabut atas keberhasilan kita yang lainnya, sehingga menjadikan kita tidak bersyukur atas segala keberhasilan yang dicapai.

Nilai Moral baik kasih sayang mencapai $18 \%$ temuan. Bentuk kasih sayang yang terdapat dalam novel "Anaka Sejuta Bintang" adalah kasih sayang keluarga, kasih sayang seorang suami terhadap isteri, isteri terhadap suami, orangtua terhadap anak dan anak 
terhadap orangtuanya. Bentuk kasih sayang seorang ayah dan pemimpin keluarga sangat kental digambarkan dalam novel Anak Sejuta Bintang melalui tokoh Bakrie. Seperti yang diungkapkan oleh Bakrie saat ingin berlibur, ia sangat ingin memberikan yang terbaik untuk keluarganya, ia berusaha villa yang akan ditempatkan nanti aman dan nyaman untuk keluarganya.

\section{Analisis Sistem Moral dalam Novel Anak Sejuta Bintang Karya Akmal Nasery Basral}

Berdasarkan kecenderungan unsur moral yang dominan muncul dalam novel Anak Sejuta Bintang karya Akmal Nasery Basral, bijaksana merupakan nilai moral baik yang paling erat kaitannya dengan Novel Anak Sejuta Bintang Karya Akmal Nasery Basral, karena Anak Sejuta Bintang menggambarkan tentang kehidupan seorang anak yang mempunyai banyak kesempatan dan prestasi dalam hidupnya, mempunyai kedua orang tua yang menjadi salah satu bintang paling terang dihidupnya, segala bentuk nasehat, motivasi yang bijaksana yang diberikan Bakrie sebagai orangtua Ical, mampu membuat Ical menemukan bintang-bintang dalam hidupnya.

\section{SIMPULAN}

Penelitian tentang aspek moral dalam novel Anak Sejuta Bintang karya Akmal Nasery Basral dapat disimpulkan seperti berikut.

1. Kecenderungan moral baik yang dapat peneliti temui dalam novel Anak Sejuta Bintang karya Akmal Nasery Basral dari keseluruhan temuan nilai moral adalah nilai moral baik bijaksana dan kasih sayang, nilai moral baik bijaksana mencapai $42 \%$ hasil temuan dan kasih sayang mencapai $18 \%$ hasil temuan.

2. Bijaksana merupakan nilai moral baik yang paling erat kaitannya dengan Novel Anak Sejuta Bintang Karya Akmal Nasery Basral, segala bentuk nasehat, motivasi yang bijaksana yang diberikan Bakrie sebagai orangtua Ical, mampu membuat Ical menemukan bintang-bintang dalam hidupnya.

3. Nilai moral yang terkandung dalam novel Anak Sejuta Bintang menjadi isyarat tentang misi yang disampaikan oleh Akmal Nasery Basral sebagai pengarang yang tetap mengutamakan nilai moral sebagai bagian penting dalam proses penciptaan karya sastra. Karya sastra tidak hanya dikaji sebagai karya yang bersifat fiksi dan imajinasi semata, tetapi harus mengandung pesan moral yang berguna dalam kehidupan nyata. 


\section{DAFTAR PUSTAKA}

Alwi, Hasan dan Dendy Sugono. 2002. Telaah Bahasa dan Sastra. Jakarta: Yayasan Obor Indonesia.

Aminudin. 1987. Pengantar Apresiasi Karya Sastra. Jakarta: Sinar Baru Algensindo.

Badudu, 2003. Sari Kesusastraan Indonesia. Bandung. Pustaka Prima.

Bakar, Abu. Benyamin. 2006. Teori Sastra. Jakarta: Universitas Indraprasta Persatuan Guru Republik Indonesia.

Esten, Mursal. Kesusastraan Pengantar Teori dan Sejarah. Bandung: Angkasa Raya.

Hanum, Zulfa. 2012. Metode Penelitian Kesusastraan . Tangerang: Unindra Press.

Hadiwardoyo, Purwa. 1990. Moral dan Masalahnya. Jakarta: Pustaka Filsafat.

Basral, Akmal Nasery. 2012. Anak Sejuta Bintang. Jakarta: Expose.

Nurgiyantoro, Burhan. 2002. Teori Pengkajian Fiksi. Yogyakarta: Rake Press.

Salam, Burhanuddin. 2000. Etika Individual Pola Dasar Filsafat Moral. Jakarta: Rineka Cipta.

Semi, Attar. 1998. Anatomi Sastra. Padang : Angkasa Raya. 1993. Metode Penelitian Sastra. Bandung: Angkasa Raya.

Suseno. Franz Magins. 1989. Etika Dasar Masalah-Masalah Pokok Filsafat Moral. Yogyakarta: Pustaka Filsafat.

Tarigan, Guntur. 2011. Prinsip-prinsip Dasar Sastra. Bandung: Angkasa Raya.

Poesporodjo. 1999. Filsafat Moral Kesusilaan Dalam Teori dan Praktek. Bandung: Angkasa Raya. 